\title{
Mewujudkan Keluarga Harmonis Melalui Pengelolaan Konflik Mertua Dan Menantu
}

\author{
Suciati $^{1}$, Nur Sofyan ${ }^{2}$ \\ 1,2 Program Studi Ilmu Komunikasi, Fakultas Ilmu Sosial dan ilmu Politik, Universitas Muhammadiyah Yogyakarta \\ JL.Brawijaya, Tamantirto, Kasihan,Bantul, Yogyakarta \\ Email: suciatiyahono@gmail.com \\ DOI: 10.18196/ppm.37.265
}

\begin{abstract}
Abstrak
Faktor penyebab konflik antara menantu perempuan dan ibu mertua antara lain: faktor pekerjaan rumah tangga, faktor ekonomi, faktor perbedaan pola pikir, faktor perbedaan pola asuh anak, faktor salah paham dan komunikasi, perbedaan kepentingan yang disertai dominasi atau paksaan oleh ibu mertua terhadap menantu perempuan. Dampak konflik yang terjadi antara menantu perempuan dan ibu mertua membuat suasana rumah tidak nyaman. Tim abdimas telah melakukan pengabdian masyarakat yang bertujuan untuk mengantisipasi terjadinya konflik pada mertua dan menantu. Abdimas dilakukan dengan mitra ibu-ibu anggota PKK desa Karasan, Kenaiban, Juwiring, Klaten. Berdasarkan hasil observasi dan wawancara yang dilakukan oleh Tim, beberapa permasalahan yang dihadapi oleh mitra terkait konflik mertua menantu, yaitu: minimnya pengetahuan relasi mertua menantu, belum memahami tentang penyelesaian konflik yang tepat dalam pasangan ibu mertua dan menantu perempuan, belum memiliki alat peraga keluarga harmonis berupa poster dan modul pembelajaran. Adapun tahapan kegiatan yang telah dilakukan, antara lain: pertama, peningkatan pengetahuan melalui penyuluhan dengan tema birul walidain atau berbakti pada orang tua. Kedua, pemutaran film dan diskusi. Ketiga, penyuluhan tentang pentingnya keterbukaan dan mengelola konflik pada pasangan mertua dan menantu. Keempat, pembuatan poster dan modul unik untuk mengkampanyekan pentingnya keluarga harmonis. Kelima, pembentukan komunitas Gerakan Sayang Mertua (GSM). Selain tahapan kegiatan tersebut, pengabdian ini direncanakan menghasilkan keluaran (ouput) berupa publikasi di Jurnal yang memiliki ISSN, publikasi di repocitory perguruan tinggi, dan publikasi di media massa, serta publikasi melalui channel youtube.
\end{abstract}

Kata kunci: mertua dan menantu, konflik interpersonal, keluarga harmonis, pengelolaan konflik

\section{Pendahuluan}

Meskipun terdengar aneh, konflik mengenai menantu perempuan dan ibu mertua adalah salah satu bahan yang menarik untuk dibahas. Apakah ketegangan dan persaingan di antara keduanya memang hal yang nyata, jelas sebabnya, bukan hal yang terlalu dibesar-besarkan? Jawabannya tentu saja nyata. Sudah menjadi rahasia umum jika menantu perempuan seringkali bertengkar atau kesal dengan ibu mertuanya. Sebagai informasi tambahan, hal ini tidak hanya terjadi di Indonesia. Perseteruan menantu perempuan dan ibu mertua terjadi di bagian dunia manapun. Perempuan memang unik. Perasaan sering digunakan sebagai sarana mengambil keputusan, sehingga apapun yang didengarnya dan dilihatnya akan dirasakannya secara mendalam. Hal inilah yang menyebabkan jarang sekali terjadi konflik di antara mertua laki-laki atau menantu laki-laki. Lucunya lagi, mertua sering dicitrakan negatif. Bahkan orang Jawa mengibaratkan tentang tanaman yang menjulur panjang sebagai "lidah mertua" karena citra seorang mertua perempuan lebih dianggap sebagai orang yang sangat cerewet. Hingga muncullah citraan bahwa berpisah rumah dari mertua setelah menikah akan lebih baik. Sebuah penelitian yang dilakukan oleh Febrian (2014) telah membuktikan adanya perbedaan kepuasan pernikahan antara pasutri yang tinggal bersama orang tua/mertua dengan pasutri yang tinggal terpisah dari orang tua/mertua.

Ada berbagai persoalan menjadi sebab tidak harmonisnya hubungan mertua menantu, antara lain perbedaan nilai dan sikap, terlalu menuntut, terlalu mencampuri urusan rumah tangga anak serta kurangnya kematangan pada pihak-pihak keluarga yang baru. Adapun hal utama yang paling sering menimbulkan perdebatan pendapat bahkan pertengkaran antara menantu dan ibu mertua lebih bersumber pada komunikasi yang tidak berjalan dengan baik. Biasanya salah satu pihak memendam ketidakcocokan mengenai sikap, kelakuan, atau hal apapun dan baru dilampiaskan setelah lama menggunung. Belum lagi kecenderungan perempuan untuk mengungkit-ungkit masalah lama, sehingga komunikasi antara dua pihak bagaikan benang kusut. Di sisi lain, budaya yang mengusung nilai merupakan faktor yang sudah mendarah 
daging dalam diri setiap orang tua. Meski anak sudah menikah, namun masih banyak orang tua yang menganggap bahwa dirinya bertanggung jawab atas kehidupan anaknya, sehingga tanpa sadar orang tua sering ikut campur dalam kehidupan rumah tangga anaknya (Mustikarani, 2012).

\section{Hasil dan Pembahasan}

Penyebab pertengkaran mertua menantu kebanyakan didasarkan pada keinginan ibu mertua yang berharap agar menantu perempuannya memperlakukan dan memanjakan anak laki-lakinya sebaik dirinya (bahkan ibu mertua biasanya ikut campur dalam urusan cucu). Ibu mertua biasanya senang menyalahkan menantu perempuan atau menganggap sang menantu tidak becus dalam rumah tangga dan membesarkan anak-anak. Padahal, ketika wanita baru berumah tangga pasti membutuhkan adaptasi. Biasanya menantu perempuan merasa tidak nyaman dengan tuntutan ibu mertua yang panjang sekali. Menantu yang tinggal serumah dengan mertua tidak merasakan kesejahteraan dalam hidupnya. Dalam hal kesejahteraan, tidak muncul begitu saja dari dalam diri individu. Padahal setiap individu harus belajar dan membiasakan diri untuk mencapai kesejahteraan itu. Kebanyakan permasalahan individu dipacu dengan perasaan yang kurang nyaman dan tidak dapat mengendalikan emosinya sehingga akan mempengaruhi kesejahteraannya (Rahmah, 2019).

Menantu perempuan biasanya tidak suka jika urusan rumah tangganya dicampuri oleh orang lain, bahkan mertua dan orang tuanya sendiri. Banyak pasangan yang tentu ingin mandiri setelah menikah, ingin belajar dan menikmati bagaimana rasanya berumah tangga. Jika ada pihak luar yang ikut campur, rasanya tidak membuat nyaman. Pada akhirnya, ada anggapan mengarungi bahtera rumah tangga tidak lagi menyenangkan Namun, mertua seringkali melakukan hal-hal yang membuat sedih menantu misalnya bersikap dominan terhadap kehidupan keluarga anaknya, lebih tahu kelemahan dan kelebihan anaknya, khawatir terhadap anaknya dan masih banyak lagi prasangka yang timbul sehingga pada akhirnya membuat tekanan kepada menantu perempuan (Rustiyaningsih, 2018)

Di sisi lain kesiapan dari masing-masing pihak untuk menerima orang lain sebagai anggota keluarga yang baru masih minim. Mertua beranggapan bahwa menantu adalah orang lain sedangkan menantu juga menganggap bahwa mertua adalah orang lain. Padahal posisi mertua atau menantu pada dasarnya adalah label saja, sedangkan esensinya adalah orang tua dan anak (Kahtleen, 1999: 217). Penyesuaian diri adalah salah satu kata kunci dari nyaman atau tidaknya menantu perempuan di rumah mertua. Hasil penelitian mengatakan bahwa kematangan emosi dan hardiness berperan penting dalam proses penyesuaian diri (Fitro, 2011). Hardiness adalah suatu konstalasi karakteristik kepribadian yang membuat individu menjadi lebih kuat, tahan, stabil, dan optimis dalam menghadapi stres dan mengurangi efek negatif yang dihadapi.

Seorang menantu bukanlah individu yang menakutkan, demikian juga dengan mertua. Posisi itu pasti dialami dalam kehidupan yang melekat dalam takdir seseorang sebagai makhluk sosial. Oleh karenanya kita perlu berpikir positif tentang siapa mertua itu, atau sebaliknya. Berpikir positif tentang mertua adalah hal yang penting bagi menantu, demikian juga sebaliknya. Para menantu harus yakin bahwa seorang mertua akan memberikan dampak positif bagi keluarga, bukan negatif. Hal ini sejalan dengan pendapat Kathleen sebagai berikut:

1. Kehadiran mertua secara psikologis akan menjamin derajat kesenangan dan stabilitas pada pasangan baru.

Penelitian yang banyak dilakukan oleh para pakar rumah tangga, bahwa prosentase perceraian dalam masyarakat yang terdiri dari keluarga besar jauh lebih sedikit daripada keluarga kecil. Dalam 
sebuah keluarga besar, yang terdiri atas suami, istri, mertua atau ditambah ipar, akan terjadi lebih banyak pertimbangan dalam pemecahan masalah daripada hanya dibicarakan berdua (suami-istri), termasuk tentang perceraian. Mertua akan banyak memberikan masukan dari langkah perceraian yang mungkin terjadi karena tidak mungkin orang tua yang baik akan membiarkan keluarga anaknya menjadi hancur.

2. Mertua sangat banyak makan asam garam kehidupan.

Dengan cara menimba pengalaman mertua, suami istri lebih bisa mengantisipasi hal yang tidak diinginkan dalam kehidupan rumah tangganya. Misalnya bagaimana merawat bayi yang baik supaya terhindar dari sakit, bagaimana memasak untuk suaminya, bagaimana merawat rumah dan isinya dengan baik, bagaimana menyenangkan hati suami di kala gundah, apalagi sang ibu pasti tahu persis kebiasaan anaknya.

3. Menggambarkan rantai masa silam.

Jika mertua dan keluarganya mampu bertahan sampai sekarang terhadap semua badai dalam rumah tangganya, maka keluarga yang baru terbentuk pun juga akan berhasil menempuh hidup sekarang ini dan di masa mendatang.

4. Kehadiran mertua akan membantu menumbuhkan kepribadian yang normal bagi cucunya.

Mertua akan menjadi tempat belajar cucu-cucunya sejauh tidak terdapat pertentangan nilai yang dimiliki oleh ibu bapaknya. Dengan demikian tugas sebagai orang tua menjadi lebih ringan.

Selain faktor di atas, tentu saja mertua memiliki andil yang sangat tinggi terhadap hadirnya rumah tangga. Andil yang dimaksud antara lain: persetujuan terhadap pernikahan, bagian dari dua keluarga yang bertemu dan bersahabat satu dengan lainnya, suatu pernikahan yang direstui oleh dua keluarga besar, serta adanya hubungan yang menyenangkan antara orang tua dan cucu.

Pertengkaran yang terjadi antara ibu mertua dan menantu perempuan bisa terjadi secara terbuka (saling adu pendapat) atau bagai perang dingin (saling diam tapi memendam kekesalan) atau saling menghindar. Tentu saja suami yang paling bingung menghadapi hal ini. Biasanya seorang suami akan bingung membela siapa. Di satu sisi sang wanita adalah istri yang harus dilindungi suami, tapi di sisi lain, suami tidak mungkin menjadi durhaka pada ibunya. Fakta menunjukkan bahwa suami cenderung meminta istrinya bersabar atau menurut saja apa yang diinginkan ibunya. Hal seperti ini banyak dipersepsikan sebagai sikap tidak adil.

Dengan konflik yang berkepanjangan, kemungkinan hubungan mertua menantu menjadi rusak. Setiawan (2007) menyebutkan beberapa faktor yang menyebabkan rusaknya hubungan mertua dan menantu, diantaranya:

1. Budaya

Faktor budaya lebih mejelaskan pada pemahaman yang keliru tentang tanggung jawab orang tua dan anak. Pada budaya tertentu, orang tua banyak berpendapat bahwa mereka harus bertanggung jawab pada anaknya meskipun anaknya sudah menikah. Orang tua merasa khawatir bahwa anaknya tidak bisa mandiri setelah menikah, sehingga orang tua harus campur tangan. Sementara anak dan menantu ingin hidup mandiri dan menginginkan mereka mengurusi rumah tangganya sendiri.

2. Ketidakmandirian anak setelah menikah

Hal ini merupakan kebalikan dari yang pertama, bahwa dalam hal ini banyak pasangan menikah tetapi masih tinggal di rumah orang tuanya. Secara finansial mereka belum mandiri. Dengan adanya campur tangan ini, maka tidak salah apabila orang tua masih mencampuri urusan rumah tangga anaknya. Misalnya saja anak mereka titipkan kepada sang nenek, sementara orang tua keduanya bekerja. Komunikasi intens antara sang nenek dengan sang cucu akan menyebabkan sang nenek menjadi protektif dengan cucunya sehingga ada kainginan selalu melindungi cucunya ketika orang tua ingin menerapkan kedisiplinan kepada cucunya. Hal ini bisa menjadi keslahpahaman. 
3. Ketidakmampuan seseorang membangun relasi antar pribadi

Ketidakmampuan ini terkait dengan kompetensi berkomunikasi dan konsep diri dari kedua belah pihak. Sifat yang mudah tersinggung, pesimis, buruk sangka, lebih menyebabkan munculnya perselisihan bukan hanya keluarga tetapi juga orang lain. Oleh karena itu diperlukan ketrampilan berkomunikasi interpersonal untuk membangun relasi antara orang tua dengan menantu perempuan. Sebagaimana hasil penelitan yang dilakukan oleh Rosyidah (2015) bahwa terdapat pengaruh keterbukaan diri terhadap ketrampilan komunikasi interpersonal antara mertua dan menantu perempuan.

4. Kepemilikan

Kepemilikan disebabkan karena kurangnya pemahaman terhadap agama. Dalam Islam, ketika anak perempuan menikah, ia menjadi milik suaminya sedangkan jika anak laki-laki meninkah, ia tetap milik ibunya. Jika hal ini tidak dipahami dengan baik, maka orang tua yang merasa melahirkan dan membesarkannya, akan merasa memiliki hak atas anaknya selamanya. Sementara sang menantu merasa punya hak atas pasangannya karena status pernikahannya. Masing-masing pihak merasakan kecemburuan satu sama lain, karena menganggap saling merebut kasih sayang dari orang yang dicintai.

Berdasarkan hasil observasi dan wawancara yang dilakukan oleh Tim Pengusul, maka dapat dipetakan beberapa permasalahan yang dihadapi oleh mitra terkait konflik mertua menantu, yaitu sebagai berikut:

1. Minimnya pengetahuan relasi mertua menantu.

Kelompok mitra di Juwiring, Klaten belum memiliki pengetahuan tentang relasi mertua menantu secara baik. Saat observasi ditemukan bahwa beberapa pasangan mertua dan menantu perempuan tampak terlibat konflik baik yang dinyatakan maupun tidak dinyatakan. Kenyataan di lapangan mengatakan bahwa relasi mertua perempuan dan menantu perempuan rawan konflik. Bahkan pernah terjadi perkelahian di antara mertua perempuan dan menantu perempuan, yang masing-masing mangaku dirinya yang benar. Menurut riset Dr. Terri Apter, psikolog dan tutor senior di Newnham College, Universias Cambridge untuk bukunya What Do You Want From Me? ${ }^{2}$ Lebih dari 60 persen perempuan mengaku mereka merasakan hubungan yang kurang sehat dengan ibu mertua. Dua-per-tiga dari seluruh perempuan yang diwawancara Apter menyatakan bahwa ibu mertua sering menunjukkan kecemburuan (Ramadhani, 2015).

2. Belum memahami tentang penyelesaian konflik yang tepat dalam pasangan mertua perempuan dan menantu perempuan. 
Kondisi di lokasi mitra menggambarkan bahwa suasana konflik antara pasangan mertua perempuan dan menantu perempuan masih sering terjadi. Adu mulut antara pasangan tidak terhindarkan meski belum sampai kepada kekerasan fisik. Jika hal ini dibiarkan maka bisa berujung pada terganggunya keharmonisan keluarga, padahal secara hakikat mertua dan menantu adalah pasangan ibu dan anak. Faktor-faktor tersebut diantaranya adalah kepribadian, perbedaan usia yang cukup jauh antara menantu dan mertua, kesamaan minat antara menantu dan mertua, peran suami yang bisa berperan sebagai penengah atau perantara antara isteri dan ibunya (Novadian, 1998).

Berdasarkan penelitian yang dilakukan oleh Mas Hana (2017), yang berjudul: Gaya penyelesaian konflik dengan mertua pada pasangan bekerja yang tinggal serumah pada 3 pasang informan menemukan hasil pada masing-masing subjek mampu menemukan gaya penyelesaian yang sesuai dengan diri mereka dan permasalahan. Ketiga pasangan subjek memiliki gaya penyelesaian konflik yang berbeda. Subjek pasangan 1 dan 2 menggunakan gaya yang sama yaitu avoidance style (menghindar). Kemampuan untuk menghindari permasalahan selalu digunakan untuk meredakan konflik. Sedangkan pasangan subjek 3 tidak menggunakan gaya penyelesaian konflik, yaitu membiarkan konflik berlalu oleh waktu. Adapun tentang hubungan tipe kepribadian dengan penyelesaian konflik diteliti oleh Kinanti, dkk (2013) bahwa terdapat hubungan antara tipe kepribadian dengan komunikasi interpersonal menantu perempuan terhadap ibu mertua. Lebih lanjut hal ini diteliti oleh Purnamasari (2013) bahwa calon mertua dan calon menantu memiliki kepribadian dan karakter yang berbeda, sehingga acapkali mengalami ketidakcocokan, dan melakukan impression management dalam komunikasi interpersonal pada masa penyesuaian sebelum pernikahan. Calon mertua lebih banyak menggunakan strategi impression management ingratiation dengan taktik favor doing dan strategi intimidation. Sedangkan calon menantu lebih banyak menggunakan strategi impression management ingratiation dengan taktik self enhancement dan strategi self promotion.

3. Belum memiliki alat peraga tentang keluarga harmonis.

Kelompok mitra ternyata belum memiliki alat peraga untuk meningkatkan pengetahuan dan kesadaran dalam pengelolaan konflik dalam keluarga harmonis. Alat peraga tersebut bisa berupa poster, modul pembelajaran yang berkaitan dengan keluarga harmonis.

Berdasarkan hasil observasi di desa Karasan, Kenaiban, Klaten, ditemukan beberapa kasus konflik mertua perempuan dengan menantu perempuan (hasil wawancara dengan Endah Sri Suranti, Ketua PKK). Beberapa konflik yang terjadi bisa dilihat dalam tabel di bawah ini:

\begin{tabular}{llll}
\hline No. & $\begin{array}{l}\text { Pasangan konflik (mertua- } \\
\text { menantu) }\end{array}$ & Sumber konflik & Bentuk konflik \\
\hline 1. & DT-DW & Tinggal serumah, ekonomi & Menghindar \\
\hline 2. & HJ-MN & Tinggal serumah & verbal \\
\hline 3. & PW-MN & Tinggal serumah, ekonomi & menghindar \\
\hline 4. & TH-ES & Tinggal serumah & verbal \\
\hline 5. & RT-TH & Tinggal serumah & menghindar \\
\hline
\end{tabular}

Metode pelaksanaan dalam kegiatan abdimas ini ditujukan untuk pemberdayaan mitra. Pemerintah melakukan upaya untuk melaksanakan pembangunan yang berpusat pada rakyat melalui pemberdayaan. Masyarakat merupakan aset yang potensial dan bisa diandalkan dalam mendukung sebuah program pembagunan. Korten (2002) menyatakan konsep pembangunan yang berpusat pada rakyat (People Centred Development) memandang inisiatif rakyat sebagai sumberdaya pembangunan yang paling utama dan memandang kesejahteraan material dan spiritual sebagai tujuan yang ingin dicapai. Pemberdayaan masyarakat pada prinsipnya merupakan upaya untuk mengubah keberadaan 
masyarakat menjadi lebih mandiri, produktif dan sejahtera. Adapun tujuan dari proses pemberdayaan masyarakat antara lain:

1. Menjadikan masyarakat mampu mengidentifikasi dan menganalisis permasalahannya sendiri,

2. Memberi fasilitas agar masyarakat mampu merumuskan beberapa alternatif pemecahan masalahnya,

3. Mendorong masyarakat agar mampu menggali mengembangkannya potensinya.

Tujuan yang akan dicapai melalui usaha pemberdayaan masyarakat ini antara lain masyarakat yang mandiri, berswadaya, mampu mengadopsi inovasi, dan memiliki pola pikir yang cosmopolitan.

Sesuai dengan permasalahan yang ada di Desa Karasan, Kenaiban, Juwiring, Klaten abdimas dilaksanakan melalui beberapa tahap yaitu:

1. Penilaian awal (initial assessment) permasalahan

Penilaian awal ini berfungsi sebagai survei awal untuk mengetahui permasalahan mitra. Identifikasi permasalahan dilakukan melalui kegiatan penyuluhan dan FGD pada kader maupun dengan pasangan mertua menantu di desa Karasan, Kenaiban, Juwiring, Klaten. Pengumpulan data dengan FGD. Karakteristik FGD terdiri atas adanya stimulus, fasilitator sebagai pemimpin jalannya intervensi yang mengarahkan dan memberikan stimulus akan topik permasalahan. Adanya interaksi dalam grup diharapkan peserta dapat saling bertukar pikiran akan permasalahan yang ada dengan peserta lain sehingga akan tercipta sebuah solusi (Dillshad dan Latif, 2013). Melalui FGD, subjek diajak untuk menyadari persoalan yang menimpa masyarakat di sekitar tempat tinggalnya dan sekaligus berusaha untuk ikut memikirkan cara mengatasi persoalan tersebut.

2. Peningkatan Pengetahuan melalui metode informatif dan persuasif

Peningkatan pengetahuan tentang permasalahan konflik mertua menantu agar timbul pengetahuan bagaimana berkomunikasi secara efektif dalam rumah tangga. Peningkatan pengetahuan dilakukan dengan berbagai penyuluhan. Keluaran dari tahap ini adalah tersusunnya modul pembelajaran tentang komunikasi intensif dalam keluarga harmonis. Dengan peningkatan pengetahuan diharapkan terjadi perubahan kesadaran dalam ranah kognitif yang kemudian diikuti dengan ranah afektif dan perilaku. Dalam peningkatan pengetahuan dimasukkan dengan metode persuasif untuk membujuk perubahan sikap. Colman (Fattah, 2010) menjelaskan bahwa persuasi merupakan proses perubahan sikap yang dilakukan oleh presentasi pesan yang bermuatan argumen-argumen, yang melemahkan atau menguatkan seseorang, objek, atau tempat seseorang dalam mengarahkan sikapnya. Dengan demikian ada 3 faktor penting yang menunjang efektif tidaknya sebuah komunikasi persuasif yaitu komunikator, pesan, dan komunikan. Ketiganya akan mengarah kepada perubahan opini, perubahan persepsi dan perubahan efek. Berdasarkan teori tersebut maka pengusul akan berusaha untuk menjadi komunikator yang kredibel, menyajikan pesan yang efektif, dan memberikan solusi sesuai dengan kebutuhan komunikan.

3. Pendampingan dan Pemberdayaan

Pendampingan dan pemberdayaan bertujuan agar nilai-nilai kesadaran tentang berkomunikasi dan penyelesaian konflik pasangan mertua dan menantu untuk diaplikasikan dalam kehidupan seharihari mereka. Menurut Prijono dan Pranaka (1996: 105-106), menyatakan bahwa pemberdayaan masyarakat harus dilakukan melalui 3 cara, antara lain:

a. Menciptakan iklim yang memungkinkan potensi masyarakat dapat dikembangkan. Hal ini diasumsikan bahwa setiap individu atau masyarakat memiliki potensi untuk mengorganisasikan dirinya sendiri. Proses ini berakar kuat pada proses kemandirian individu tersebut, yang meluas prosesnya ke masyarakat yang lebih luas.

b. Potensi yang telah dimiliki masyarakat diperkuat dengan menerapkan langkah-langkah nyata, menampung berbagai masukan, menyediakan prasarana baik fisik maupun sosial yang dapat diakses oleh masyarakat yang paling bawah. Dengan terbukanya akses pada berbagai peluang akan menjadikan masyarakat semakin berdaya, baik dalam bidang politik, ekonomi, maupun sosial. 
c. Memberikan perlindungan dan membela kepentingan masyarakat yang lemah. Hal ini untuk menghindari persaingan yang tidak sehat dan tidak seimbang. Demikian juga melindungi dari eksploitasi yang kuat atas yang lemah. Berdasarkan 3 jenis definisi tentang pemberdayaan masyarakat, maka definisi kedua yang paling sesuai dengan kegiatan abdimas ini. Pengusul memberikan langkah-langkah konkrit kepada subjek dalam rangka mengembangkan potensi yang telah dimiliki oleh masing-masing mertua dan menantu. Prasarana fisik berupa poster dan video yang dapat diakses subjek sangat membantu memunculkan potensi tersebut. Demikian juga dengan prasarana sosial yang berupa peningkatan pemahaman tentang birul walidain dan managemen konflik mertua menantu.

4. Pembentukan komunitas

Komunitas ini merupakan bentuk pendampingan agar program yang dilaksanakan dapat memiliki keberlanjutan. Anggota komunitas adalah para pasangan mertua perempuan dan menantu perempuan yang secara rutin didampingi untuk melakukan diskusi dan motivasi. Komunitas ini dilengkapi dengan grup komunikasi WhatsApp untuk membantu kelancaran komunikasi. Pada dasarnya pembentukan komunitas ini juga merupakan langkah nyata yang dilakukan subjek sebagai solusi jangka panjang untuk mengantisipasi munculnya kembali masalah.

Pelaksanaan kegiatan abdimas sebagai sebuah solusi direncanakan sebelum pandemi Covid 19 dengan peserta seluruh anggota PKK desa Kenaiban, Juwiring, Klaten. Namun dalam kenyataannya rencana jumlah peserta berubah dengan penyesuaian protokol kesehatan yaitu maksimal 20 orang.Tahap kegiatan mulai dari identifikasi masalah sampai dengan pelaksanaan program:

1. Wawancara dan Focus Group Discussion (FGD)

FGD bertujuan untuk mengidentifikasi lebih rinci terkait konflik mertua menantu. FGD ini melibatkan kader, dan pasangan mertua menantu. Selain itu, juga dilakukan pengukuran tingkat pemahaman pasangan mertua menantu terhadap relasi dalam keluarga.

2. Penyuluhan komunikasi mertua menantu dalam keluarga harmonis

Penyuluhan ini dilakukan untuk meningkatkan pengetahuan dalam menjalani kehidupan rumah tangga pada pasangan mertua menantu. Penyuluhan ini bertujuan untuk meningkatkan kesadaran pasangan mertua menantu dalam keluarga. Kesadaran ini diterapkan dalam kehidupan sehari-hari dengan menerapkan program keluarga harmonis. Santi (2015) meneliti tentang peran komunikasi interpersonal dalam menjaga hubungan yang harmonis antara mertua dan menantu perempuan. Dalam penelitiannya ditemukan data bahwa tingkat keterbukaan dan keharmonisan antara menantu dan mertua perempuan diketahui $63 \%$ mengalami hubungan terbuka dan harmonis, tingkat komunikasi antara menantu dan mertua perempuan sebanyak 53\% dinyatakan menantu dan mertua perempuan sering melakukan komunikasi dengan baik. Adapun data membuktikan sebanyak 52\% hubungan antara menantu dan mertua perempuan dinyatakan tidak ada masalah. Penyuluhan dilakukan sebanyak 2 kali, dengan menghadirkan narasumber yang ahli dalam bidang komunikasi. Tema penyuluhan meliputi:

a. Birul walidain

b. Managemen konflik interpersonal dalam pasangan mertua menantu

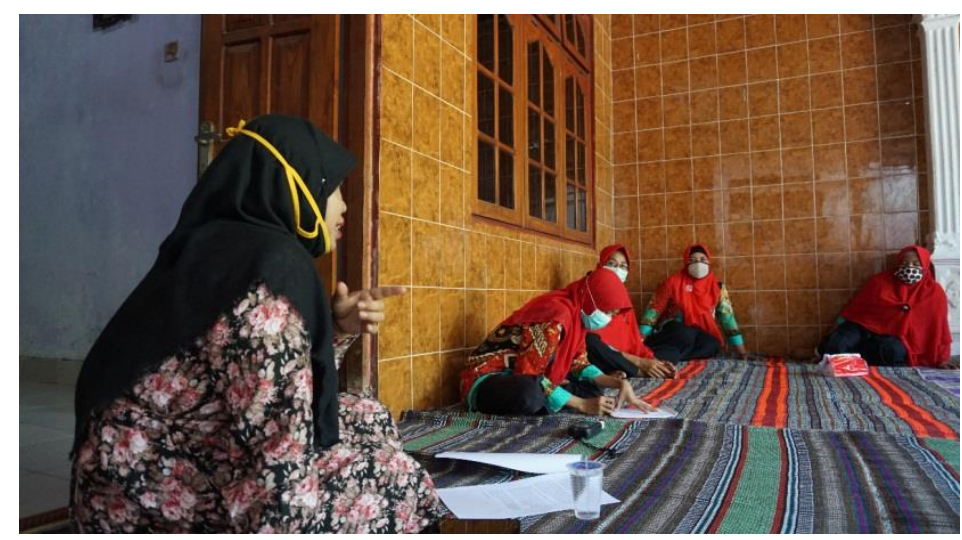


Gambar 1: Foto penyuluhan managemen konflik dalam rumah tangga

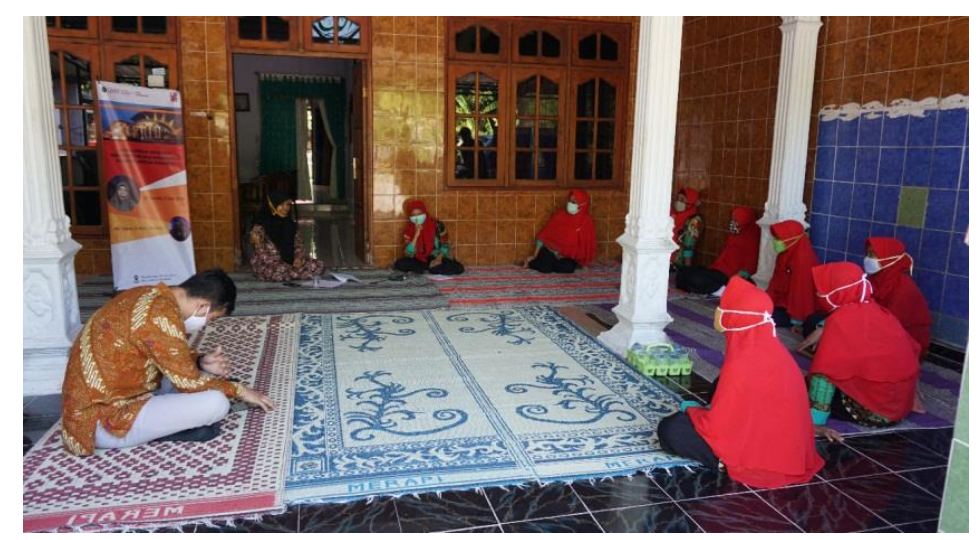

Gambar 2: Foto penyuluhan birul walidain

3. Penayangan film tentang akibat pertengkaran mertua menantu dan diskusi

Penayangan film di sini bermanfaat sebagai media literasi dalam memahami seluk beluk dan dampak konflik mertua menantu. Setelah itu dilakukan diskusi dan simulasi tentang isi film. Dengan demikian pasangan yang bersangkutan dapat mengungkapkan kesulitan maupun keinginan terhadap pasangan. Keterbukaan antar pasangan menjadi semakin terlihat. Demikian juga keterbukaan terhadap pasangan lainnya.

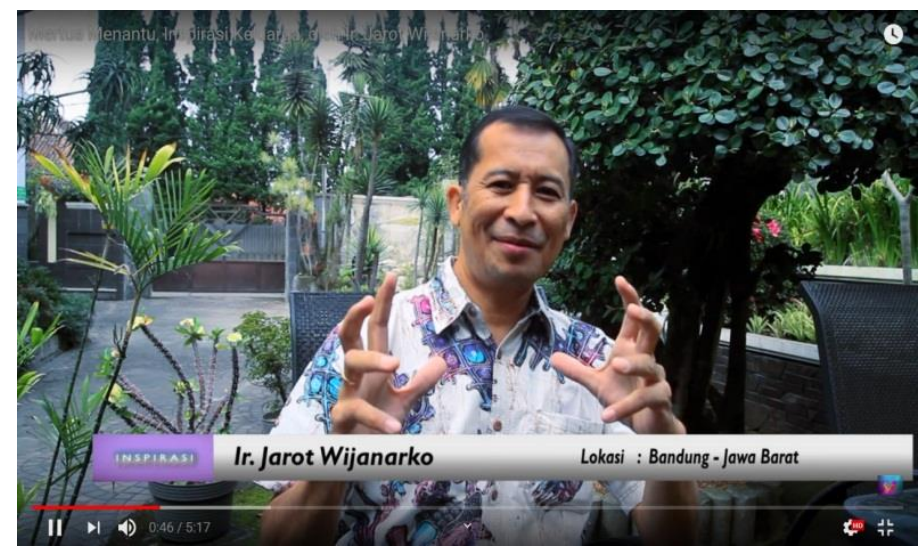

Gambar 3: Foto cover film motivasi

4. Pembuatan modul dan poster keluarga harmonis 
Pembuatan modul dan poster di sini bertujuan untuk menjadi retention dalam setiap pasangan mertua menantu ketika menjalin komunikasi. Isi modul dan poster meliputi penanaman kesadaran untuk selalu berkomunikasi intens dan terbuka dengan pasangan, sehingga konflik bisa terhindarkan.

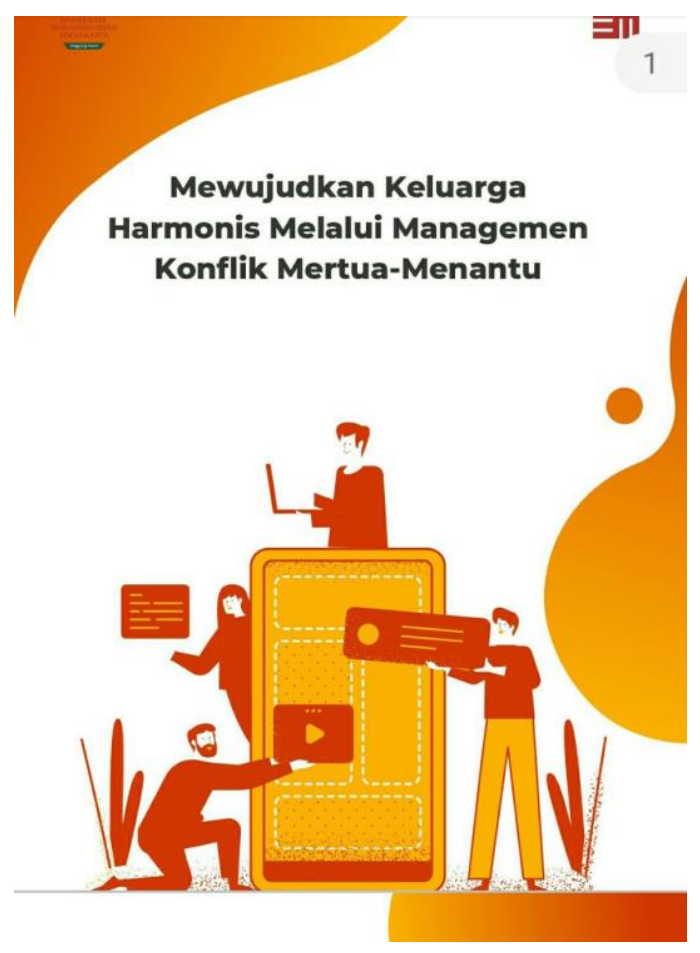

Gambar 4: Modul kegiatan

\section{Pembentukan Komunitas dengan nama Gerakan Sayang Mertua (GSM)}

Pembentukan komunitas ini bertujuan untuk menunjang keberlanjutan program komunikasi intens dalam keluarga harmonis, sehingga ada anggota penerus yang akan menjadi pengerak terkait pencegahan konflik mertua menantu. Komunitas ini nantinya akan beranggotakan pasangan mertua menantu. Melalui komunitas ini juga nantinya bisa dirumuskan kegiatan-kegiatan untuk mendukung terwujudnya keluarga harmonis.

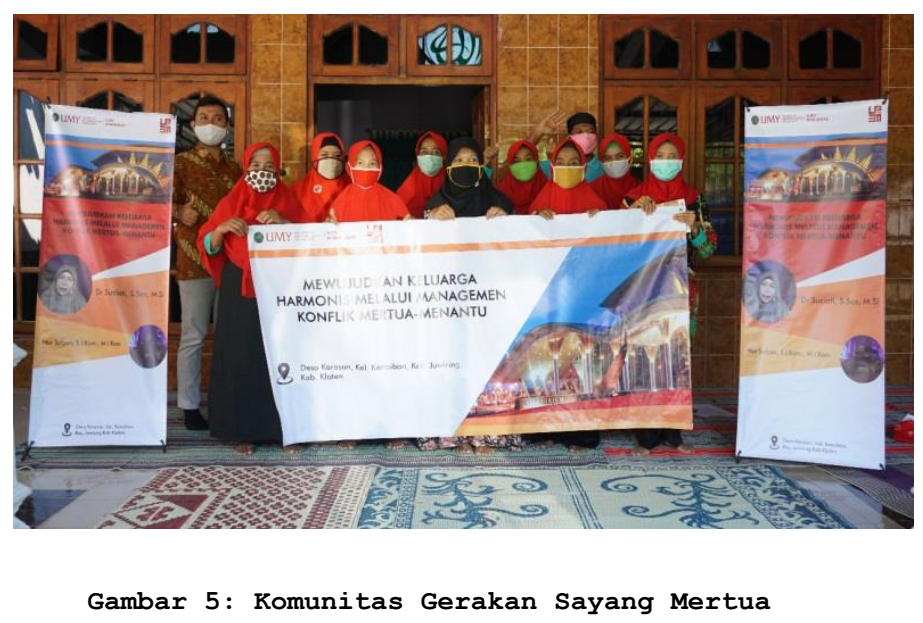

Adapun pelaksanaan publikasi dilakukan melalui media massa harian Jogja dan youtube. 

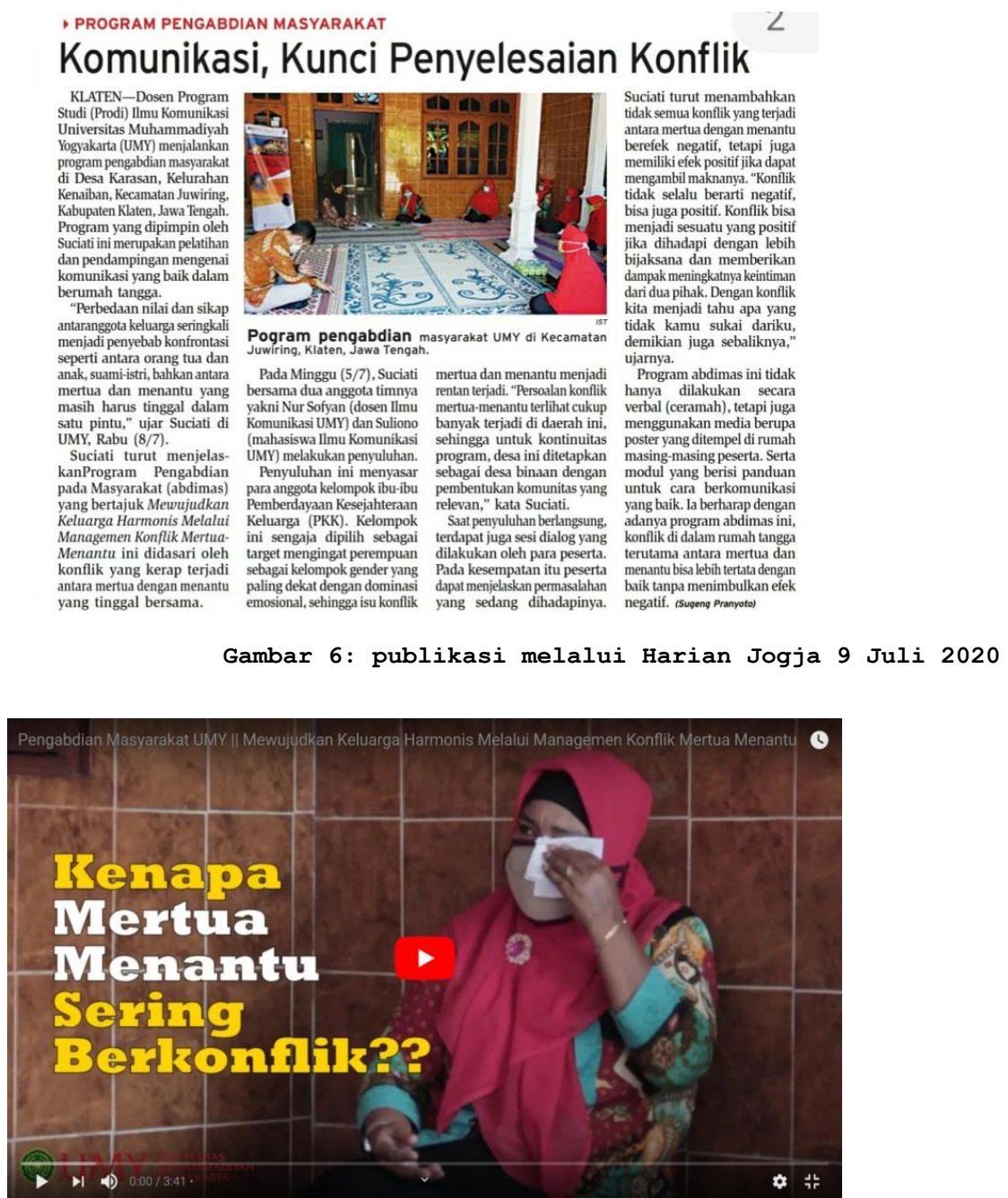

Gambar 7: Publikasi dengan link channel youtube : 8kuGJhsVak

\section{Simpulan}

Pelaksanaan abdi masyarakat di Juwiring Klaten pada tanggal 5 Juli 2020 dengan tema "Managemen Konflik Mertua Menantu dalam Mewujudkan Keluarga Harmonis” diterima dengan suka cita oleh mitra pengabdian, yaitu ibu-ibu pengurus PKK desa Kenaiban, Juwiring, Klaten. Peserta hanya terbatas pengurus, mengingat suasana masih dalam Pandemi Covid 19, sehingga pertemuan tatap muka tetap harus mengikuti protokol kesehatan. Persoalan konflik antara mertua dan menantu diungkapkan oleh ibu-ibu dalam sesi tanya jawab dengan Tim abdimas. Tahapan pelaksanaan yang dilakukan oleh tim meliputi penayangan film sesuai topik, sesi penyuluhan dan tanya jawab, penyerahan poster dan modul penyuluhan, serta pembentukan gerakan sayang mertua. Adapun luaran yang sudah dilaksanakan adalah publikasi di media massa Harian Jogya 9 Juli 2020, pembuatan youtube, serta publikasi ke jurnal pengabdian yang mimiliki ISSN. Dengan demikian kegiatan abdimas ini diharapkan tetap berkelanjutan sebagai upaya memberikan pemberdayaan masyarakat sebagai konsekuensi dari pelaksanaan Tri dharma Perguruan Tinggi.

\section{Persantunan}


Dengan terlaksananya program abdimas di desa Karasan, Kenaiban, Juwiring, Klaten dengan efektif dan efisien, maka tim abdimas sudah seharusnya untuk mengucapkan terimakasih kepada pihak-pihak yang terkait. Pertama, pihak LP3 UMY yang telah memfasilitasi berupa pendanaan kegiatan abdimas, sehingga kegiatan ini bisa berjalan lancar. Kedua, terimakasih kepada mitra abdimas, yaitu ibu-ibu PKK desa Karasan, yang telah berpartisipasi hadir dan mendukung kegiatan sampai selesai. Tanggapan dan pertanyaan peserta telah mencerminkan keterlibatan secara emosional terhadap topik abdimas. Ketiga, kepada semua mahasiswa yang telah membantu teknis pelaksanaan abdimas, mulai dari dokumentasi, pembuatan video youtube, serta monitoring selama kegiatan berlangsung.

\section{Referensi}

Korten, D. C, (2002). Menuju Abad Ke-21, Tindakan Sukarela dan Agenda Global. Jakarta: Yayasan Pustaka Obor Indonesia.

Kuntaraf, Kathleen, dan Jonathan Kathleen, (1999). Komunikasi Keluarga: Kunci Kebahagiaan Anda. Jakarta: Indonesia Publishing House

Prijono,O.S., Pranarka, A.M.W, (1996). Pemberdayaan: Konsep, Kebijakan dan Implementasi. CSIS, Jakarta.

Setiawan, Robi (2007). Hanya maut yang Memisahkan Kita, Semarang: e-Konsel 4 Agustus 2008. Vol. 2008. No. 165

Jurnal:

Dilshad, R. M., \& Latif, M. I. (2013). Focus Group Interview as a Tool for Qualitative Research : An Analysis. Journal of Social Sciences, 33(1), 191- 198.

Fitro, Siti Fadjryana, (2011). Hubungan Antara kematangan Emosi dan Hardiness dengan Penyesuaian Diri Menantu Perempuan yang Tinggal di Rumah Ibu Mertua, Psikoislamika : Jurnal Psikologi dan Psikologi Islam Vol 8, No 1 (2011)

Kinanti, Josefine Ayu dan Hendrati, Fabiola, (2013). Hubungan Tipe Kepribadian dengan Komunikasi Interpersonal Menantu Perempuan terhadap Ibu Mertua, Jurnal Psikologi Tabularasa, Vol 8, No 2 (2013)

Purnamasari, Dian ( 2013). Strategi Impression Management pada Komunikasi Interpersonal antar Calon Metua dalam Masa Penyesuaian Sebelum Pernikahan, Jurnal E- Komunikasi, Vol 1 No 2 (2013)

Rustiyaningsih, Tia, (2018), Konflik Mertua sebagai Hambatan Generasi Komunikasi Lintas Budaya, Jurnal ilmu Komunikasi Andalan no 1 volume 1 (2018)

Rahmah, Milda, dkk, (2019). Konflik Sosial Menantu Yang Tinggal Serumah Dengan Mertua (Studi Kasus Di Desa Lempang Kecamatan Tanete Riaja Kabupaten Barru), Equilibrium jurnal pendidikan, Vol 7, No 2 (2019)

Rhosyidah, Kholifatur, (2015). Pengaruh keterbukaan diri (self disclosure) terhadap keterampilan komunikasi interpersonal menantu perempuan pada ibu mertua di daerah Karanganyar Probolinggo, Undergraduate thesis, Universitas Islam Negeri Maulana Malik Ibrahi

Santi, Yuyun (2015). Peran Komunikasi Interpersonal dalam Menjaga Hubungan yang Harmonis antara Mertua dan Menantu Perempuan, publikasi.iunitri.ac.id, Volume 4 No 3 (2015)

Saputra, Febrian, dkk (2014). Perbedaan Kepuasan Pernikahan antara Pasutri yang Serumah dan Terpisah dari Orangtua/Mertua, Jurnal Riset Aktual Psikologi, Volume 5 No 2 (2014)

Internet:

Ramadhani, Mutia (2015). Supaya Akur, jadikan Ibu Mertua Sekutu yang Baik, diakses darihttps:/www.republika.co.id/berita/nasional/daerah/16/03/30/gaya- 
hidup/parenting/15/01/09/nhw61y-supaya-akur-jadikan-ibu-mertua-sekutu-yang-baik, $\quad$ pada 10 Nopember 2020

Mas Hana, Isa , (2017) Gaya penyelesaian konflik dengan mertua pada pasangan bekerja yang tinggal serumah, digilib.uinsby.ac.id, tanggal 4 September 2020

Mustikarani, Wahyu (2015). Hubungan Mertua dan Menantu yang Tinggal dalam Satu Rumah, diakses dari repository.unej.ac.id pada 4 September 2020.

Novadian, Ariana, (1998). Persepsi menantu terhadap kualitas hubungan dengan ibu mertua (Studi kualitatif pada 4 menantu perempuan yang tinggal di rumah mertua 1-2 tahun), diakses dari http://lib.ui.ac.id/bo/uibo/detail.jsp?id=94212\&lokasi=loka pada 10 Nopember 2020 